\title{
Milton and the Tradition of Protestant Petrarchism
}

\section{Abstract}

Scholarly accounts of Milton's engagement with Petrarch often suggest a hostile reading of the Italian poet's work. The Protestant ideal of Adam and Eve's companionate marriage in Paradise Lost has been seen as a rebuke to the unfulfilled petrarchan lover and his chaste mistress; the seductive language of petrarchan pleading has been traced in Satan's tempting speeches. In Of Reformation (1641), however, Milton invoked Petrarch as an authority in the Protestant cause. This paper seeks to reconstruct the alternative tradition of petrarchism which underlies Milton's reference. It explores the international network of Protestant polemicists and writers among whom it originated, and looks at its influence on works in English, including Spenser's earliest poems, which precede $O f$ Reformation; it considers the bibliographical evidence for Milton's reading of Petrarch; and it argues that the politicised and protestantised Petrarch provided an important model for Milton's own religious sonnets. 


\section{Milton’s Petrarch}

There are two arresting aspects to Milton's citation of Petrarch in Of Reformation, his 1641 treatise on the government of the English church. ${ }^{1}$ One is that he invokes the authority of a Catholic, and a tertiary of the Franciscan Order, in a Protestant polemic; the other is that he appears - somewhat uncharacteristically - to make a mistake. This is the reference, with what seems to be Milton's own translation from the Canzoniere: Petrarch seconds him [Dante, whom he has just quoted] in the same mind in his 108. Sonnet which is wip't out by the Inquisitor in some Editions; speaking of the Roman Antichrist as meerely bred up by Constantine.

Founded in chast and humble Povertie,

'Gainst them that rais'd thee dost thou lift thy horn, Impudent whoore, where hast thou plac'd thy hope?

In thy Adulterers, or thy ill got wealth

Another Constantine comes not in hast. ${ }^{2}$

The mistake is the number of the sonnet, which is not 108 , but 138 - easily attributed perhaps to a slip of the pen, but I will return to that question below. I would like to begin by considering the nature of Milton's engagement with Petrarch. There have been many studies of Milton the italianist, and for good reason. He spent much of 1639 in Italy, and his was not idle travelling, especially from a literary perspective: he was befriended by writers, and welcomed by various of the academies which met to compose and discuss poetry. He spoke Italian at least well enough to compose six of his early poems in the language, which in turn argues for a reading knowledge adequate to those Italian texts which critics have traced in the hinterland of his own writings. Of these, scholars have tended to be interested in the works of Dante, who, as another writer of religious epic, perhaps offers the most obvious parallels; or those of Giovanni della Casa, whose poems we know to have been in Milton's library: his copy still survives. ${ }^{3}$ Petrarch, on the other hand, has been relatively neglected. Although he looms large in studies of early-modern English writing, even so comprehensive an account of Milton's Italian sources as Milton in Italy (1991) has little to say about Petrarch, except to suggest in passing that the Canzoniere was not a particularly important model for Milton's sonnets. ${ }^{4}$ This essay will argue, to the contrary, that Petrarch's sequence contains a particularly 
resonant model for Milton's distinctive approach to the sonnet, and it will also suggest that his use of Petrarch in Of Reformation is the key to that connection.

That Petrarch has been overlooked as a model for Milton's sonnet-writing might be accounted for by the widely-accepted theory that petrarchan imitation had fallen out of fashion in England by the early seventeenth century. Nonetheless, Milton's critics have registered the poet's awareness of Petrarch in relation to Paradise Lost, and do not seem to consider the vagaries of fashion as an impediment to his engagement with Petrarch's work in that connection. In an article called 'Milton's dialogue with Petrarch', Ilona Bell read what she terms the 'mutual, dialogic love' of Adam and Eve as 'an English critique of Petrarchan self-absorption'. ${ }^{5}$ Barbara Lewalski referred to the 'Petrarchan perversions' of Satan, and William Kerrigan and Gordon Braden identified the fallen angel as the 'arch-petrarchist' of Paradise Lost. ${ }^{6}$ Anthony Low argued that the mature Milton's depiction of 'Satanic posturing in the temptation of Eve' dealt a deathblow to '[e]ver-desirous Petrarchan love - now diminished to little better than a comical cousin of incestuous narcissism? ?

These readings of the manner of love in paradise are, on their own terms, very persuasive, but they do not account for the entirety of Milton's response to Petrarch. He was not always hostile to petrarchan love, as his early poetry demontrates. The Italian sonnets present us with familiar vignettes from the Canzoniere - like Petrarch, he admires his lady's singing, he praises her beautiful eyes - and he helpfully points to his sources by later describing one of his English sonnets as 'a petrarchian stanza'. ${ }^{8}$ Some considerable scholarly energy has been expended in arguing that Milton in fact intended to undermine petrarchan poetics through the Italian verses - so, for instance, much significance is attached to the fact that the lady he addressed is dark, rather than, as Petrarch's Laura, blonde. (That this might reflect mere personal preference has not been widely entertained.) For instance, Lara Bovilsky, having identified the texts as an example of 'English petrarchism', rejects any possibility of a straightforward reading: instead, she suggests that 'the reader may interpret the Italian as a surface, the poem as palimpsest, revealing Milton's wholesale critique of the emotions, national fluidity, and Italian temptations he conjures." These readings might be measured against Milton’s 1638 letter to the philologist Benedetto Buonmattei, where he refers to his pleasure in Petrarch's work; ${ }^{10}$ and, lest we take that to refer to the philosophical writings, Milton addresses the love poetry in the Apology for Smectymnuns of 1642, when he speaks of 'the two famous renowners of Beatrice and Laura, who never write but honour of them to 
whom they devote their verse, displaying sublime and pure thoughts, without transgression. ${ }^{11}$

These references may seem to set up a contradiction between Milton's praise of Petrarch's love poetry, and his own putative anti-petrarchism; but rather than assuming a change of heart on Milton's part, we might look instead to the anti-papal quotation in $O f$ Reformation. This sonnet has nothing in common with the courtly petrarchism detected in the speeches of Satan or Eve in Eden - but it is, nonetheless, a sonnet by Petrarch. Milton's translation gestures towards a body of Petrarch's sonnets which are not accommodated in our received account of English petrarchism; it demonstrates that there is a distinction to be drawn between Petrarch, and petrarchism - that is, between the poet's own works, and the name of a style which has been filtered through the writings of his translators, his imitators, and crucially, his modern scholarly interpreters; ${ }^{12}$ and it hints at an alternative petrarchism running parallel to the love poetry of early modern English writing.

It has been long recognised that sixteenth- and seventeenth-century English sonneteering was fuelled by multiple paraphrases of a relatively few, popular poems from the Canzoniere. These were love sonnets, although the Canzoniere is also a repository of political poems, addresses to patrons, poems of friendship, and so on; and these love poems were taken from the first section of the text, the In Vita di Madonna Laura, rather than from the more sombre verses written after Petrarch (at least ostensibly) heard the news of his mistress's death. They provided the familiar motifs of beloved enemies, icy fires, and a chaste, unavailable, but desirable woman, whose very unavailability doomed the lover to failure and unhappiness. The translations tended to distort Petrarch's work, and their account of petrarchan love as one-sided, fruitless, and often idolatrous, was the object of much criticism from Protestants in particular: its language of devotion sounded suspiciously Catholic, the sexual puns it frequently introduced were considered indecent, and its valorisation of the frustrated lover runs counter to the ideal of companionate marriage. As an ideology, this English rendering of Petrarch is a more likely target in Paradise Lost than the original 'sublime and pure thoughts' Milton praised. The contradiction, it seems, stems from a problem of nomenclature: it is the critics and not Milton who have called Satan a petrarchist, or identified Eve's coyness with Laura's tantalising coldness. Milton may have come to dislike aspects of poetry in this style, but he would not necessarily have designated them as petrarchan. As his translation of 'Fontana di dolore' shows, he had read the Canzoniere beyond the few source-texts which 
underlay a multitude of English paraphrases. Furthermore, in this wider knowledge, he was not alone: for Milton, as for large numbers of his contemporaries, there was more to Petrarch than love poetry. Amorous petrarchism might have been the most fashionable literary mode of its day, but the real best-seller of early-modern England was Foxe's Book of Martyrs - a text which went through multiple editions, and from 1570, was required by a series of directives to be made available for public inspection in cathedrals and parish churches. ${ }^{13}$ It could hardly have escaped the attention of the English public that, among his lists of witnesses to the faith, Foxe had named that Italian Catholic churchman, 'Franciscus Petrarcha'. ${ }^{14}$

The sonnet by Petrarch which Milton translates in Of Reformation falls outside the usual account of petrarchism in English. It is one of a group of three poems, 'Fiamma dal ciel', 'L'avara Babilonia' and 'Fontana di dolore', which are commonly known as the Babylon, or Avignon, sonnets. They were written during the papal exile from Rome in the fourteenth century, after Pope Clement V had removed the Holy See to Avignon. Petrarch, who was in minor orders, was attached periodically to the court, and his impression was distinctly unfavourable. The sonnets are bitter attacks on what he perceived as the luxury and corruption of the Avignon papacy, and on the very fact of its exile from Rome - what Petrarch termed its Babylonian Captivity. The poems are part of a small body of works on the same theme. A further sonnet in the Canzoniere, number 114, 'De l'empia Babilonia', also treats of the Avignon court; and Petrarch produced a series of prose writings on the subject. In 1368, he sent a letter to the Pope, Urban V, arguing that he should return to Rome. ${ }^{15}$ Some years later, when the papacy had briefly reestablished itself in Rome, and removed again to Avignon, Petrarch received a copy of an attack on his first letter by the French theologian, Jean d'Hesdin. Petrarch's response, the Invectiva contra eum qui maledixit Italie (Invective against a detractor of Italy) revisited the same topics of Rome's virtues and Avignon's flaws. ${ }^{16}$ He took a much more provocative approach in a second series of familiar letters on the subject: these, the Liber sine nomine, as the title suggests, could only be safely circulated without the names of recipients. ${ }^{17}$ The sonnet texts are inflammatory enough in themselves - Milton's translation, above, is a fair representation - and the other two poems, if anything, are more lurid, with Beelzebub firmly established at the court, and the destruction of 
Babylon fondly imagined. ${ }^{18}$ They were to become much more inflammatory, however, when the new religious context of Reformation Europe radically altered the significance of Petrarch's words.

The Protestant identification of the biblical Babylon with the Roman Church, as popularised by Luther's 1520 treatise On the Babylonian Captivity of the Church, allowed these texts to be reinterpreted as anti-papal in the broadest sense - that is, as critical of the institution of the papacy, rather than a particular aspect of its history - and Petrarch's Babylon writings began to circulate in Reformed communities, first on the continent and then in England. They appeared in new editions of the Canzoniere where their anti-papal meaning was fixed by the marginal glosses of a series of protestantising commentators. Even when the poems circulated as individual texts without the buttressing of a commentary, writers found other means to guarantee the interpretation of Babylon. One of the first English translations of 'Fontana di dolore' is that of John Harington the Elder, written c. 1547. The first quatrain of his source-text runs as follows: Fontana di dolore, albergo d'ira, Fountain of sorrow, dwelling of wrath, scola d'errori, et templo d'eresia, school of errors, and temple of heresy, già Roma, or Babilonia falsa et ria, once Rome, now false wicked Babylon, per cui tanto si piange et si sospira. for whom there is so much weeping and sighing. Harington adhered closely to Petrarch's text until he came to the allusive reference to Rome and Babylon. He omitted the place-names, and substituted his own interpretative gloss:

Spring of all woe, $\mathrm{O}$ den of curssed ire,

Scoole of errour, temple of heresye;

Thow Pope, I meane, head of hypocrasye,

Thow and thie churche, unsaciat of desyre. ${ }^{19}$

That Petrarch had intended his words to carry this specific meaning was not disputed by his Protestant readership. The extent to which this misinterpretation was wilful is difficult to determine: Petrarch's witness was too valuable to permit the dilution of its force by debate and qualification. Rather than displaying any anxiety about whether the meaning of Babylon had changed over the intervening two centuries, readers preferred to describe the works as prophetic, and Catholic arguments to the contrary were given short shrift. George Abbot, then Vice-Chancellor of Oxford, and later, Archbishop of Canterbury, exemplified this approach in The Reasons which Doctour Hill hath brought, for the upholding of papistry. 
The same opinions concerning the Pope and Rome, did that rare man Franciscus Petrarche seeme fully to embrace, as may appeare to any who will reade his workes, howsoever Cardinall Ballarmine labour to make the worlde beleeve otherwise, beeing desirous to haue us thinke, that Petrarch spake not against the Pope, but some abuses in the Courte of Rome. $^{20}$

Abbot, writing in 1604, was a late-comer to the dispute. Over forty years earlier, in 1559, the Roman Inquisition had responded to the adoption of the sonnets for the Protestant cause by ordering them to be excised from existing editions of the Canzoniere, and excluded from new printings: this is the censorship that Milton noted in $O f$ Reformation. ${ }^{21}$ The Inquisition's instructions were performed with varying degrees of enthusiasm. In some cases the pages containing the sonnets have been cut out; ${ }^{22}$ in others, scrupulous readers adhered to the spirit as well as the letter of the law, and deleted other anti-papal poems like Sonnet 114, or scribbled over the reference to the Babylon sonnets in the index. ${ }^{23}$ There are other copies, however, where the poems have been highlighted with a marginal note or manicule and the anti-papal editorial comments marked in approbation. ${ }^{24}$ Finally, in many cases, no action at all has been taken, and it is now impossible to tell whether the text was owned by an obstinate, ill-informed or uninterested Catholic, or by an equally uninterested reader living beyond the reach of the Inquisition's censors.

The Inquistor's task was a hopeless one: almost one hundred and forty editions of Petrarch's sonnets had been produced between the first printing, by Wendelin of Speyer, in 1470, and their appearance on the Index. By the mid-sixteenth century, these copies were scattered around the world. The University Library in Cambridge holds one edition (Y.8.60), which was printed in Venice in 1544. Various inscriptions reveal that it passed into the possession of a Spanish owner, who brought it with him to the Spanish garrison at Santo Domingo, now in the Dominican Republic. That colony was attacked by Francis Drake in January 1585/6, and the book was seized during the looting by one William Yue, who - after a voyage to Roanoake, North Carolina - brought it home to Northampton as a gift for his schoolboy brother, Paul, a student of Italian. Paul recorded the volume's history on the flyleaf, in a painstaking hand, and in every language he could muster. Y.8.60 had, perhaps, an unusually eventful career, but many other copies must simply have been sold to Protestant countries. Not only could the Inquisition not reach 
these books, its condemnation seems only to have enhanced their importance in reformed circles.

The existence of this Protestant Petrarch has not gone unnoticed. Robert Coogan has written on the Liber Sine Nomine and the papacy, and Abigail Brundin has discussed petrarchism in the literature of the Italian reformation. ${ }^{25}$ William Kennedy provided a survey of the Italian commentaries on the Canzoniere in his Authorising Petrarch, which included an account of three protestantising glosses, by Sebastian Fausto da Longiano, Ludovico Castelvetro, and Antonio Brucioli. ${ }^{26}$ The history of the Babylon sonnets on the continent has received some attention: Catharina Ypes wrote about their use in Dutch polemic in her 1934 study of petrarchism in the Low Countries, and more recently, Jean Balsamo has considered some of their ramifications in a 2006 essay on readings of the Canzoniere in sixteenth century France. ${ }^{27}$ In the context of 'prophetic', gospelling, English verse, Andrew Taylor looked perceptively at the Babylon sonnets as a model for the Earl of Surrey's London invective, and David Norbrook even discussed Milton in this connection, in an important, but tantalisingly brief, account in Poetry and Politics in the English Renaissance. ${ }^{28}$ Editions of Milton's writing will mention these sonnets in their notes. However, they do so only briefly: even in a book dedicated to Milton and the sonnet, like Anna Nardo's Milton's Sonnets and the Ideal Community, they are confined to an endnote. ${ }^{29}$ What has been lacking is a sustained account of the existence of this alternative petrarchism, for Milton specifically, and in early modern English writing generally. And yet, this was a model of immense significance, current all over Europe from at least the mid-sixteenth century, keeping pace with Petrarch's secular fame. It was written into histories of the reformation and even preached from the pulpits. It could hardly have eluded any early modern reader, least of all one as thorough as Milton.

Even before the edict of the Inqusition, editions of the Canzoniere complete with the Babylon sonnets, and editorial commentaries to expound on their significance for Protestant readers, were in circulation. They were soon joined by a body of texts which were more explicitly designed as polemic, and which culled the letters and sonnets from the larger volumes of Petrarch's works and reprinted them in the company of other antipapal writing. The earliest, to my knowledge, of these polemical anthologies appeared in 1554, a tiny pamphlet containing the Babylon sonnets, but no information as to its place of origin or its printer. ${ }^{30}$ It also contained a letter 'to the Christian reader', instructing him or her as to the application of the sonnets, and signed by the obviously pseudonymous 'Hilario'. Hilario transpired to be the apostate papal nuncio and bishop 
Pier Paolo Vergerio, who clearly felt anxious about the publication being traced to him; but no such concerns about secrecy attended Matthias Flacius Illyricus two years later when he produced his Catalogus testium veritatis (Catalogue of witnesses to the truth) in Strasburg. In this substantial compendium of criticism of the papacy, which was to appear in at least eight more editions over the next hundred years, Petrarch sits alongside the other authorities Milton cites in OfReformation, Dante and Ariosto - as well as a few less likely opponents of the papacy: Flacius began with several pages of proofs from no less an authority than St Peter himself. This collection was an extremely popular resource, and may account for the similar, if more concise, anthologies of anti-Catholic witnesses appended to other texts from the same milieu: Lambert Daneau's Tractatus de Antichristo (Treatise concerning Antichrist) (Geneva, 1576) concluded with - amongst others - selections from Bernard of Cluny, Gregory the Great and the Babylon sonnets, which were printed in both Latin and Italian. And, to give just one more of many possible examples, the sonnets were also published, this time translated into Dutch, in De byenkorf der H. Roomsche kerke (the Beehive of the Romish Church), by Philips van Marnix van St. Aldegonde in 1569.

One of the noteworthy characteristics of the use of Petrarch in antipapal polemic is the implicit emphasis on the literary quality of the works. The poems often appear in the company of other poems or extracts from writers whose style was well-regarded. There appears to have been a desire to amass a library of modern greats who could be co-opted for Protestantism - which provides an interesting counter-example to those early-modern Protestant writers who were at pains to set religion and literary endeavour at odds during the Reformation. ${ }^{31}$ Vergerio's edition printed the Babylon sonnets alongside some verses by Francesco Berni, author of various popular satires on the Curia. Similarly, the Huguenot writer Francois Perrot published an anti-papal Catholic collection in 1586, as part of a controversy initiated when Pope Sixtus V excommunicated Henry of Navarre. ${ }^{32}$ Perrot proposed to retaliate through poetry, and suggested that a collection of anti-papal texts be drawn from the three greatest authorities in Italian vernacular literature: Dante, Boccaccio, and Petrarch. His book presents the excerpts from all three familiar from compilations like the Catalogus testium veritatis, and naming the Babylon sonnets, goes on to quote the first in full. Eleven lines into the second, however, the reader encounters an entirely new stanza, composed by Perrot, supporting Petrarch's accusations. The next sonnet begins as usual; however, Perrot has kept only the familiar opening words; the rest of the sonnet, while preserving 
Petrarch's rhyme words, is another original contribution to the debate - and this turns into a sequence of twenty-seven more sonnets which paraphrase and elaborate the original three poems. Some of them commend Petrarch or Dante by name. It is a very literal-minded effort at following his own advice and creating a body of anti-papal literature.

The title page of Perrot's book announces that it was printed in Monaco, by one Giovanni Swartz; more interesting in respect of Milton, perhaps, is the truth, which is that it was issued from the press of John Wolfe in London. Perrot's book, written by a Frenchman in Italian and printed in England, casts the international nature of earlymodern Protestantism, and Protestant writing, into relief. It is important to emphasise that, just as amorous petrarchism had moved across Europe from at the beginning of the sixteenth century, so also the polemical texts were conveyed through the same languages and countries. Almost all of the continental texts I have cited had appeared in English translation by the end of the sixteenth century. Marnix's Byenkorf was translated by George Gilpin - including the Babylon sonnets - and was printed in 1579 as The Bee Hiue of the Romishe Church. Daneau's Tractatus was translated by John Swan and published in 1589: and the editor appended not one, but two English renderings of the sonnets to the end of the work. ${ }^{33}$ It seems that after receiving a completed English translation of the copy-text, which included the sonnets, he spotted another version in Thomas Howell's Devises, a collection of verse from 1581, and decided to print both. In keeping with the emphasis on his literary excellence so common in these works, Petrarch is introduced here, not as an anti-papal authority, but as the 'very prince of Italian poets'. ${ }^{34}$

Petrarch's name is also emphasised in a 1595 London publication of parts of Francesco Guicciardini's Storia d'Italia. ${ }^{35}$ This history had originally appeared in 1561-4, and was immediately adopted into the vernacular canon - but prior to its publication, a judicious editor had excised certain acerbic passages on the temporal power of the Church, and also, more colourfully, on the family life of Pope Alexander VI. These sections came to light in 1569 when they were printed by Pietro Perna in Basel. ${ }^{36}$ The London edition provided an English translation; it also printed Petrarch's Babylon sonnets, in a new translation, at the head of the text. The connection between the works is perhaps not strong (they criticise different aspects of the papacy) but it was nonetheless enduring. When Robert Dallington published his Aphorisms Civil and Militarie in 1613, he included an appendix on Guicciardini, in which the Babylon sonnets appeared yet again, newly rendered into English for the occasion. ${ }^{37}$ 
In addition to these printed texts, there are various manuscript translations of individual sonnets from this group. I have mentioned John Harington's texts in the Arundel MS, which Ruth Hughey dates to 1547 in her edition. The same year, or shortly afterwards, the Protestant martyr John Philpot wrote a version of 'Fontana di dolore', in a manuscript now held at the British Library. ${ }^{38}$ The text is undated, but its dedication 'To the mighty and excellent Prince, the Duke of Summersett', whom he describes as 'protector' to 'our sovereign king Edward the sixth' puts it between February 1547, when Somerset's title was created, and October 1549, when the protectorship was dissolved. ${ }^{39}$ In the seventeenth century, it was translated once more, this time, by the parliamentarian general Thomas Fairfax, to whom, in turn, Milton had dedicated a sonnet of his own. ${ }^{40}$

I have no doubt that these lists of both printed and manuscript copies are incomplete; however, even as they stand, they make a sizeable quantity. ${ }^{41}$ It has been widely maintained that the most widely translated of Petrarch's sonnets, at least into English, is 134, 'Pace non trovo'. There are versions by Wyatt, Thomas Watson, Robert Southwell and others. But there are certainly more translations of the Babylon sonnets. Arguments for the importance of Petrarch in English love poetry, however, rest upon the enormous range of paraphrases and loose imitations of his work dispersed through English writing generally, rather than on the slighter body of precise translations. Nonetheless, the same logic might be applied to the political and religious texts. Petrarchan influence has been hunted by critics through the canon of secular love poetry. Polemical writing, meanwhile, has been left relatively undisturbed in the search. Through the lens of the Babylon sonnets, this body of work comes into focus. What has seemed like a series of anomalous texts is revealed as coherent body of paraphrases and imitations, which constitute a tradition of Protestant petrarchism.

The English Tudor sonnet has been broadly conceived of as a love poem. As I have already suggested, this is because petrarchism was received as the lover's idiolect, and was also irrevocably associated with the sonnet form. Generations of scholars have done little to change this equation, spelt out in the middle of the last century in J. W. Lever's seminal study, which he tellingly called The Elizabethan Love Sonnet. ${ }^{42}$ What reappraisal has taken place has suggested that the petrarchan terminology of secular love could equally be redirected towards heaven in the form of devotional poetry - as in, for instance, John Donne's Holy Sonnets. Another school has treated sequences of love sonnets as political texts, which conceal ambition under the terms of a familiar and conventional system of language. Little has been said about English sonnets on explicitly 
political or polemical themes, for various reasons. One is, presumably, that they cannot easily be accommodated in this school of thought in which the language of love is so crucial. Another, perhaps, is that the texts are not to be found in the usual places. Translations of the Babylon sonnets come up as often in a controversial treatise as they do in a manuscript miscellany. However, their relative invisibility to us does not mean they were not well known in their time. Like the petrarchism of love poetry, they have also left their mark on a much broader field of literary texts, as in the following examples.

In 1579, a little-known writer called Bernard Garter published a curious collection which he called $A$ Newyeares Gifte, dedicated to the Popes Holinesse, and all Catholikes addicted to the Sea of Rome. It is a miscellany of anti-Catholic material, assembled, says Garter, to thank the pope for the relics recently sent into England - of which there is a foldout leaf, illustrated with rosary beads and medals. Some of the familiar loci from the continental anti-papal catalogues are included, as are some specifically English texts concerning Reginald Pole and others; and there is a short sonnet sequence on the subject of the papacy. ${ }^{43}$ It is unsurprising that this should be less than flattering. It runs through a number of common arguments - that the papacy has no foundation in scripture, that it has destroyed the Church by which it rose - the only unusual element is that the arguments are carried out in sonnet form. The fourth sonnet suggests that Petrarch lurks in the background, because Garter uses it to treat of the subject (one might have thought, impossible to versify) of the Donation of Constantine. Lorenzo Valla even makes an heroic appearance in the octet. However, this is not unprecedented in verse, because Petrarch invoked Constantine in the Babylon sonnets. Many of the editors of the Canzoniere worked Valla into their commentaries on the poem, and although Garter is not translating or even paraphrasing Petrarch's texts, his choice of subject and verse form associate him with the same tradition.

A similar instance arises in the mid 1590s, in the works of Barnabe Barnes. Barnes was already known for his sonnets, although his Parthenophil and Parthenophe (1593) is surely the only amorous sequence of the period in which the rejected lover resorts to black magic, and rape, to attain union with his mistress. In 1595, he turned his attention to devotional poetry, and produced a fresh sequence, the Divine Centurie of Spiritual Sonnets. These poems are not unlike the roughly contemporary religious sonnets by Henry Lok, William Alabaster and Henry Constable - those of which critics have broadly said that the terms of secular petrarchism are redirected into heavenly love - except that the group of poems clustered about the half-century are not the devotional, heavily- 
scriptural texts of the rest of the work: they are incongruously polemical attacks on the papacy. Shortly after the publication of this sequence, Barnes was forced to go on the run after a series of spectacularly inept attempts to poison the Recorder of Berwick: Mark Eccles gives a wonderful account in Thomas Lodge and Other Elizabethans (1933). ${ }^{44} \mathrm{It}$ was some years before he reemerged onto the literary scene, but he announced his return with a new play, The Devil's Charter (1607). This is a work clearly influenced by Marlowe. Like Faustus, Barnes' protagonist sells his soul to the Devil in exchange for the granting of a wish: in this case, Rodrigo Borgia desires to be pope (he becomes Alexander VI). And, just as The Jew of Malta was narrated by a Machiavell, the Devil's Charter has its own illustrious Italian chorus, this time, Francesco Guicciardini. Barnes took the bones of his play from those censored sections of Guicciardini which were circulated by Protestant printers along with the three Babylon sonnets; so, although the connection between Petrarch's polemical sonnets and those by Barnes is not at all as explicit as that between Barnes' play and Marlowe's, nonetheless, it seems that he knew the texts, and it seems likely that they provided a precedent for the anti-papal turn taken by his Divine Centurie.

There is still less doubt about the sources underlying Alexander Garden's 1609 collection miscellany of prayers and occasional lyrics, A garden of grave and godlie flowers. One poem, the 'Description of the World', might make us pause.

What is this World, a Theater of woe? A gulfe of greif, that still the greater growes, A Faire where fooles, are flitting to and fro, A Sea of Sorrow, that still ebs and flowes, A Forge where Belial the bellowes blowes, A Shippe of sensuall Soules, neir sunk for sinne Whair ramping Rage, is Ruther-man and rowes, A wratched Vasl, full of all Vice within, A Booth of busines where restles rin To wrack himselfe, the wicked worldly worme, A deadly Den, of dolor, and of din, An onstai'd Stage, of State, a strife, a storme,

Th'vnquiet Court, of discontent and Cair, The Place of Pride, and well-spring of Dispaire. ${ }^{45}$ (G4)

The sonnet does not engage with religious dispute - it is part of the contemptus mundi tradition - but its language is familiar. Garden's 'gulfe of greif, 'Place of Pride, and wellspring of Dispaire', and even the forge of Belial (although Petrarch has Beelzebub at the furnace) are too close to the diction of the Babylon sonnets for coincidence. It appears that Petrarch's poems had permeated literary conscious sufficiently to allow for a broader application of their tropes. 
Garden's opening line, conjuring up the world as theatre, leads neatly to my final example. Just as the Babylon sonnets appear in the footnotes to Milton's poems, so they also merit a nod in discussions of Spenser's Visions of the World's Instability. Jan Van Der Noot, a Protestant religious exile from the Low Countries, arrived in London in 1567, and shortly afterwards published French and Dutch editions of a book called the Theatre for Worldlings. An English edition followed two years later. The text was heavily based on Petrarch: it consists of six epigrams and eleven sonnets based on Canzoniere 323, a shorter sequence of four apocalyptic sonnets by Van Der Noot, and a prose commentary on the moral significance of the poems, which runs to over two hundred pages. The epigrams and sonnets derive from Petrarch via translations by Marot and du Bellay; for the English edition, they were translated once more, this time by the very young Edmund Spenser. In The Theatre for Worldlings, they are called Visions of the World's Instability, but they reappear, in edited form, in 1591, under the title of 'The Visions of Petrach'. We do not need this formal acknowledgement of Petrarch to show that Spenser knew who had written his ultimate source-text: despite the intervening layers of Marot and du Bellay's translations, Petrarch is a prominent figure in the Theatre for Worldlings, discussed at length in Van Der Noot's commentary. The translations do not come from the typical texts of anti-papal petrarchism; Canzoniere 323 is a series of allegorical visions concerning the death of Laura. It is significant that even his amorous poetry seemed suitable for employment in an anti-papal text: it suggests that, at least in certain circles, the image of Petrarch the proto-Protestant loomed as large as that of Petrarch the lover. There has been no doubt of Spenser's familiarity with the latter. Various incidents in The Faerie Queene $(1590,1596)$ and his own sonnet sequence, the Amoretti (1595) indicate a close, if occasionally mocking, engagement with the petrarchan tradition of love poetry. ${ }^{46}$ The Visions of the World's Instability shows that a writer could keep both incarnations of the poet before his eyes.

Despite this precedent, Milton is widely credited with the transformation of a genre associated in English with private and confessional love poetry, into a public, political and prophetic form. ${ }^{47}$ This is so well established a concept that an undergraduate text like the Cambridge Companion to Milton refers to 'the Miltonic model of the occasional and political sonnet' which it traces to Della Casa and Tasso; when Milton turned to them in the seventeenth century, we are told, this represented a new departure because for English readers 'the sonnet was concerned with human love and sometimes, as in Donne and Herbert and one or two memorable occasions in Spenser, with divine love. ${ }^{48}$ 
Besides Della Casa and Tasso, models for Milton's sonnet have been found in Horace, Aristotle, and others - all valid contributions, and it would undoubtedly be ill-advised to set limits on the scope of Milton's reading. Nonetheless, by the seventeenth century, there is no case to be made for the novelty of English sonnets on themes other than love. It simply is not true to say, as Janel Mueller does in an otherwise excellent article, that Milton 'pioneered the writing of political sonnets in English. ${ }^{49}$ The examples of Garter, Barnes and Spenser - an unknown, a marginal and a canonical writer - are unified by their choice of the sonnet form as vehicle for religious and political comment, and although their poems might invoke the divine, they do not, despite the Cambridge Companion, concern themselves particularly with divine love. Milton may be one of the brightest stars in a hundred-year-old tradition of English political sonneteering, but he was not its progenitor.

Milton knew Petrarch in all of his guises. If the early Italian sonnets suggest that he was familiar with the love poems from the Canzoniere, 'Upon the Circumcision' indicates that he read the devotional lyrics too: his elaborate rhyme-scheme is borrowed from 'Vergine bella', the hymn to the Blessed Virgin which concludes the sequence. ${ }^{50}$ Petrarch also provided a model for Milton's mature sonnets. The declamatory and public mode of 'To the Lord General Cromwell' or 'On the Lord General Fairfax at the siege of Colchester' is a departure from the 'petrarchian stanzas' of the juvenilia, where his invocations to a nightingale or to his friend Charles Diodati are part of private conversations. There are precedents in the Canzoniere for public address: 'Spirito gentil' (53) and 'Italia mia' (128) establish the poet as a voice for his nation, invoking a leader on its behalf. These poems are canzoni but the same concerns can also be seen expressed in sonnet form:

Waiting for justice I struggle and grow weary; but I see a new sultan for [Babylon] ... her idols shall be scattered on the ground and her proud towers, enemies of Heaven; and her tower-keepers shall be burned from the outside as from within. Beautiful souls, the friends of virtue, shall hold the world, and then we shall see the age become golden and full of the ancient worthiness. ${ }^{51}$ 
Milton, writing after the victory of his cause, could be more specific than Petrarch, who still awaited the reform he desired. Cromwell, Fairfax, Skinner are all given their proper names, and set in the context of battles fought and careers pursued, whereas Petrarch veiled his meaning under classical figures, giving his poems a deceptively abstract and universal air. The declamatory mode and apocalyptic diction is common to both, however:

... new foes arise

Threatening to bind our souls with secular chains:

Help us to save free conscience from the paw

Of hireling wolves whose gospel is their maw. ('Cromwell', 11. 11-14)

Elsewhere, the vocabulary as well as the mood overlaps. 'On the late Massacre in Piedmont' (1655) is Milton's response to the slaughter of the Waldensians in April of that year by the army of Charles Emmanuel II, Duke of Savoy. The Waldensians had a long history of dissent from the Catholic Church, and were seen as precursors of the Reformation - the rights of the survivors were championed by Protestants internationally. As Latin secretary, Milton prepared the letters sent by Cromwell to various European powers in the aftermath of the massacre, and seems to have composed the sonnet at the same time.

Avenge O Lord thy slaughtered saints, whose bones

Lie scattered on the Alpine mountains cold,

Even them who kept thy truth so pure of old

When all our fathers worshipped stocks and stones,

Forget not: in thy book record their groans

Who were thy sheep and in their ancient fold

Slain by the bloody Piedmontese that rolled

Mother with infant down the rocks. Their moans

The vales redoubled to the hills, and they

To heaven. Their martyred blood and ashes sow

O'er all the Italian fields where still doth sway

The triple Tyrant: that from these may grow

A hundredfold, who having learnt thy way

Early may fly the Babylonian woe.

It is a poem which bears comparison with Petrarch's, although the perspective is conspicuously different. Milton's 'truth so pure of old' refers to the Protestant tradition 
of tracing their religious origins to the apostles; his 'stocks and stones' seem intended to signify the statuary of the Catholic tradition. There are idols in the Babylon sonnets, but they are more likely to refer to Venus and Bacchus (and their attendant vices), established in the poems as the reigning gods in the papal court. Similarly, Petrarch's pope is not Milton's faceless 'triple Tyrant': it was the Avignon exile, and not the papacy itself, to which he objected. ${ }^{52}$ However, the two poets merge in the final line. Milton's use of the incongruous 'Babylonian' is the key to his subtext. The term is surprising because the argument in the case of the Waldensians did not concern the pope: the political representations on their behalf by Cromwell were directed instead to the Duke of Savoy. The command that they renounce their faith, and the decision to mobilise an army to expell them from their homes, originated with him. The invocation of Babylon makes the poem more specifically anti-papal; in the context of a sonnet written according to Petrarch's rhyme scheme, it also serves to associate the poem with the tradition of Protestant petrarchism. Like John Harington's translation a century before, Milton invites a rereading in which Petrarch's images are assigned new meanings. The 'Babylonian woe' is the hint to the reader that in this poem, Milton was doing no less than appropriating, and rewriting, the Babylon sonnets.

Commentators on Shakespeare's Sonnets (1609) often remark that he was a late-comer to the genre: amorous sonnet sequences were at the height of their popularity in the 1590s. Protestant petrarchism proved more enduring. Milton could have read new publications citing the Babylon sonnets and the Liber sine nomine throughout his lifetime. ${ }^{53}$ They were included in many texts we know to have been of interest to him. He had, for instance, been aware of the Waldensians well before the troubles of 1655 - there are references to them in his Commonplace Book, and in the political writings of the $1640 \mathrm{~s} .{ }^{54}$ There is some debate about where he read their history, which circulated in various compendia in Reformed circles; however, it seems likely that he would have found Petrarch in many of the texts he might have consulted. The 1508 Excusatio fratrem $W$ aldensienses is one of the most frequently anthologised Waldensian documents, and this defence of their creed one with great similarity to Milton's own religious beliefs - closes with three full pages of quotation from Petrarch's Liber sine nomine. The association clearly continued into the 1650s. Samuel Morland, who had been Cromwell's special ambassador to the Duke of 
Savoy in the aftermath of the massacre, published a book in 1658 describing all of the diplomatic transactions surrounding the incident, and providing a history of the Waldensian people. His introduction covers many of the same themes as Milton's sonnet: the ancient faith of the Waldensians is established: to those Catholics 'demanding of us where our Religion was before the daies of Calvin and Luther ... witness for us, that it was in the Valleys of Piemont.$^{55}$ The Papal court is compared with Babylon; and he quotes the verse (Rev. 6:10) which Milton paraphrases in his poem, imagining the dead Waldensians in heaven 'crying, How long O Lord, holy and true, wilt thou cease to avenge our bloud upon them who dwell upon the earth? $?^{56} \mathrm{He}$ also cites the three Babylon sonnets, reprinting two in full, and giving a quatrain from the third $\left(\mathrm{c}^{\mathrm{r}-\mathrm{v}}\right) \cdot{ }^{57}$ Milton may have been involved in Morland's book - there is some debate about whether he wrote the remonstrance Morland delivered to Charles-Emmanuel, so this overlap may not be coincidental. It is clear, however, Petrarch was a conspicuous presence in Waldensian literature, and that the Babylon sonnets were a natural model for Milton when he came to commemorate that community in verse.

This strong connection notwithstanding, there are other places where Milton might have earlier encountered Petrarch's Protestant incarnation. His Commonplace Book proves his reading of Guicciardini's Storia d'Italia, which is mentioned above; but although Ruth Mohl traced the references to a 1636 Florentine edition, this omits the censored chapters. ${ }^{58}$ It seems likely that Milton would have sought out a corrected version, and of the subsequent English editions alone, three include the Babylon sonnets. There is also a transcription of one of the sonnets, taken from the English version of the Beebive of the Romish Church, in a commonplace book in the Bodleian. ${ }^{59}$ This manuscript belonged to Joseph Mede, the fellow of Christ's who was friend and mentor to Milton during his time at the College. The catalogue describes the book as Mede's juvenile work: however, internal evidence suggests that its contents cannot date from much earlier than 1619, bringing it enticingly close to Milton's arrival at Christ's in 1625.

It is clear that, although he may have been influenced by the broader cultural climate of petrarchan imitation and citation, Milton knew the poems in their original context, in the Canzoniere. It would be interesting to know which edition of Petrarch he used, because the reader's sense of the poems is much affected by the literature of commentary which had rapidly grown up around the sequence. Sebastian Fausto da Longiano's edition (Venice, 1532) was designed for aspiring poets: it came with an index of the epithets employed in the sonnets, ready to be copied into a commonplace book to 
ornament future compositions, and it had a dictionary of Petrach's rhyme-words (a rimario), also ripe for recycling in new poems. Twenty years later, Girolamo Ruscelli's edition (Venice, 1554) set out to appeal to those, like the members of the academies which later played host to Milton, who were interested in the reform of the vernacular. It emphasised the updated and corrected orthography of the text, and provided a dictionary of Petrarch's pure Tuscan vocabulary. Bernardino Daniello (Venice, 1541) laid particular stress on the literary excellence of the poems. Many presented the Canzoniere as an autobiographical love story, with portraits of Laura and maps of the countryside where she lived. The most popular of these was Alessandro Vellutello's edition (Venice, 1525), which was reprinted 29 times. Castelvetro (Basle, 1582) and Brucioli (Venice, 1548) picked up the religious aspects of the poems, and found in them material which they could assimilate with their own involvement in Protestant reform. However, by the time Milton was writing $O f$ Reformation, there were about 150 printed editions available to him of the Canzoniere alone, besides Petrarch's other works.

Jackson Campbell Boswell, in his painstaking Milton's Library: A Catalogue of the Remains of John Milton's Library and an Annotated Reconstruction of Milton's Library and Ancillary Readings (New York, 1975), could find no evidence of Milton's ownership of a particular edition of Petrarch. He speculated that he might have read his Opera (no edition specified), the Apologia contra Gallum, and the Italian poems: here, he suggested Le Rime del Petrarca brevemente sposte per Ludovico Castelvetro as the likely version. ${ }^{60}$ Given Castelvetro's religious sympathies, this seems a reasonable choice - but Milton gives us a clue to the contrary.

It may well be that Milton did use a copy of the Castelvetro Petrarch, but not when he was writing OfReformation: the Babylon sonnets were omitted from all copies published after 1569, and in those printed prior to that date, 'Fontana di dolore' was numbered 107. Milton gives the number of the same poem as 108. This is the mistake I mentioned at the outset: the standard edition is the Aldine text of 1501, according to which Milton's sonnet is number 138. However, when that sonnet is quoted in Morland's History, he notes in the margin that he used the edition printed by Augustino de Zanni de Polese in Venice, 1515 - and he calls it Sonnet 110. There were almost as many systems of numbering the sonnets as there were editions, and Milton's slip turns out not to be a slip at all, but rather, an accurate reference to the numbering used in his copy.

This narrows the field considerably, but there remain several editions which share this system. Choosing between them is difficult. Many citations of the poems by the 
Protestant writers discussed here give no sonnet number or bibliographical details. Some, like the 1595 edition of the missing chapters of Guicciardini, like Milton, only give numbers (in this case, they give the same number, 108). At times, it is possible to be more specific. There is an unusually precise reference in Simon Birckbeck's The Protestant's Evidence of 1634. He works through the evils of Catholicism (after the fashion of the Magdeburg Centuries) a hundred years at a time, and eventually reaches the fourteenth century, when, he says, 'Petrarch calles Rome Babylon'. ${ }^{61}$ He supports this statement with reference to 'Fontana di dolore' and 'De l'empia Babilonia', and with a marginal note directing the reader to 'Basil. 1581', that is, the 1581 four-volume Opera, printed in Basle by Sebastian Henricpetrus, a reprint of the 1554 text from the same press. This is the edition owned by Thomas Goad, author of The Friers Chronicle (1623) which invokes 'L'Avara Babilonia' as evidence against the Catholic hierarchy. His copy is now in the library of King's College, Cambridge. Similarly, William Guild's Anti-Christ pointed out in his true colours (Aberdeen, 1655) quotes Petrarch several times, alluding in general terms to 'Petrarcha epist.' and 'Epist. 18'. In one instance, however, he is more specific. He cites a passage from Petrarch, beginning 'Vides enim non modo CHRISTI adversarium.... ${ }^{62}$ The marginal note mentions to Petrarch's letters, but also gives a page reference: 803 , a reference which likewise corresponds with the passage as printed in the 1581 edition.

The Basle text is well-positioned to appeal to Protestant reader. The book introduces Petrarch as 'the most famous poet of our age' and then adds that he was 'the scourge of the Babylon of the West and of the Pope'. ${ }^{63}$ It contains, not only the Babylon sonnets in an unexpurgated text, eleven years after the Inquisition's edict, but also, the Liber sine nomine in full. Its 'Life of Petrarch' recounts a story beloved by Protestant controversialists, that Petrarch was offered a cardinal's hat in exchange for his sister's virtue (the noble and disinterested poet refused). Its credentials were sufficiently good that the parishioners of Bury St Edmunds kept it in their church library, where it was the only book of the collection which is not ostensibly religious. ${ }^{64}$

There were other libraries which valued these qualities. Christ's College Cambridge owns a copy of the 1554 printing. This may be a red herring, since - despite their kind help - neither the librarians nor I succeeded in finding any record of when the book entered the collection; however, it was far from the only copy available to Milton in the libraries of Cambridge, as we know from Elisabeth Leedham-Green's work on private libraries in the University. ${ }^{65} \mathrm{I}$ suggest it tentatively as a source for Milton's reading 
of Petrarch, but I assert more strongly that it enshrines an aspect of petrarchism which he knew well, and which exerted a strong influence on his own writing. With - perhaps this edition in the College collection, with Joseph Mede and his commonplace book installed in ground floor rooms below the library, and with a wealth of continental and English precedents for political and religious sonneteering, deriving from the Babylon sonnets, it seems a certain thing that Milton's Petrarch - political, proto-Protestant, and authoritative - was a more formidable creature than the obsessive lover apparently targeted when Satan encounters Eve in the garden of Paradise Lost.

\section{Endnotes}

${ }^{1}$ [Blank for acknowledgements.]

2 Of reformation touching church-discipline in England: and the causes that bitherto bave bindred it, in Don M.

Wolfe (ed.), The Complete Prose Works of John Milton, vol. 1 (New Haven, 1953-82), 559.

${ }^{3}$ On the influence of Della Casa, see F.T. Prince, The Italian Element in Milton's Verse (Oxford, 1962), 14-33; for his possession of an edition of Della Casa's sonnets, see Anna Nardo, Milton's Sonnets and the Ideal Community (London, 1979), 8. 
${ }^{4}$ Mario A. di Cesare (ed.), Milton in Italy: Contexts, Images, Contradictions. Vol. 90, Medieval \& Renaissance Texts \& Studies (New York, 1991); see especially Michael R. G. Spiller, "Per chiamare e per destare': Apostrophe in Milton's Sonnets', 477-88 in that volume.

${ }^{5}$ Ilona Bell, 'Milton’s Dialogue with Petrarch’, Milton Studies, 27 (1992), 91-120 (93).

${ }^{6}$ Barbara Kiefer Lewalski, 'The Genres of Paradise Lost', in Dennis Danielson (ed.), The

Cambridge Companion to Milton (Cambridge, 1999), 113-29 (124); William Kerrigan, and Gordon

Braden, 'Milton's Coy Eve: Paradise Lost and Renaissance Love Poetry', ELH, 53 (1986), 27-51

(43).

${ }^{7}$ Anthony Low, The Reinvention of Love: Poetry, Politics and Culture from Sidney to Milton (Cambridge, 1993), 200.

${ }^{8}$ The letter to an unnamed friend containing this description, and the text of Sonnet VII ('How soon hath time') is contained in the Trinity MS, and reproduced in Complete Prose Works 1:320.

${ }^{9}$ Lara Bovilsky, 'Black Beauties, White Devils: The English Italian in Milton and Webster', ELH, 70 (2003), 625-51 (635).

${ }^{10}$ With his characteristic modesty, the young Milton had remarked, 'Certainly I, who have not merely wet my lips in these Languages but have drunk deeper drafts - as much as anyone of my years, am nevertheless glad to go for a feast to Dante and Petrarch.' Complete Prose Works I:330.

11 Complete Prose Works I:890.

${ }^{12}$ See, for instance, Leonard Forster's The Icy Fire (Cambridge, 1969) for a distinction between Petrarch's own writing, and the more various literary tradition of petrarchism.

${ }^{13}$ For details of the Privy Council's, and other, directives on this subject, see John N. King, Foxe's Book of Martyrs and Early Modern Print Culture (Cambridge, 2006), 112-3.

${ }^{14}$ John Foxe, Acts and Monuments (London, 1570), at 16, where Petrarch appears among the 'authors alleged in this book', and 492, where he is cited in detail as a witness against the papacy. 15 Petrarch, Letters of Old Age / Rerum Senilium Libri I-XVIII. ed. Aldo S. Bernardo, Saul Levin and Reta A. Bernardo. 2 vols. (Baltimore and London, 1992), I:IX.

${ }^{16}$ Petrarch, Invectives. ed. David Marsh, I Tatti Renaissance Library (London, 2003), 364-475. 
${ }_{17}$ These letters are reprinted in Petrarch's Book, without a Name: A Translation of the Liber Sine Nomine, ed. Norman P. Zacour (Toronto, 1973).

${ }_{18}$ Per le camere tue fanciulle et vecchi / vanno trescando, et Belzebub in mezzo (Through your chambers young girls and old men go frisking and Beelzebub in the midst); 'Gl'idoli suoi sarranno in terra sparsi, / et le torre superbe, al ciel nemiche, / e i suoi torrer di for come dentro arsi' (Her idols shall be scattered on the ground and her proud towers, enemies of Heave; and her tower-keepers shall be burned from the outside as well as from within.) Text and translations of Petrarch's Canzoniere are taken throughout from Petrarch's Lyric Poems: the Rime Sparse and other lyrics, ed. and trans. Robert Durling (Cambridge MA, 1976).

${ }_{19}$ The Arundel Harington Manuscript of Tudor Poetry, ed. Ruth Hughey, vol.1 (Columbus, OH, 1960), 381.

${ }^{20}$ George Abbot, The Reasons which Doctour Hill hath brought, for the upholding of papistry, (Oxford, 1604) 56.

${ }^{21}$ Index Librorum Probibitorum (Rome, 1559) sigs. F1'-v. The ban relates to a 'Liber inscrip. Alcuni importanti luochi tradotti suor delle Epistole latine di M. Francesco Petrarca ... con tre Sonetti suoi, \& xviii Stanze del Berna.' The book in question was edited by Pier Paolo Vergerio (Vergerius).

22 See Cornell Petrarch PQ 4476. B38a [copy one], where a [nineteenth-century?] owner has tipped in a replacement page containing 'De l'empia Babilonia', 'Fiamma dal ciel' and 'Fontana di dolore' to replace either a badly defaced or a missing leaf.

${ }^{23}$ St Catharine's College Cambridge, JI/5/3 [Sonetti e Canzoni di Messer Francesco Petrarca] 1553 (114, 'De l'empia' is inked out in the text); Pembroke College Cambridge 3.29.24 Le Opere Volgari di Meser Francesco Petrarcha. Venice, 1511. 'L'avara' is deleted from the table of contents.

${ }^{24}$ See for example King's College Cambridge XV.8.11, Petrarcha con l'esposizioni di Bernardo Ficino. Milan, 1494. A sixteenth- or seventeenth-century reader has added a manicule next to each title, and in the case of 'Fiamma dal ciel', which has two commentaries, the anti-papal interpretation is highlighted with a further manicule; the other reading is marked with an X. 
${ }^{25}$ Robert Coogan, 'Petrarch's Liber Sine Nomine and a Vision of Rome in the Reformation', Renaissance and Reformation, 7 (1983), 1-12; Abigail Brundin, 'Petrarch and the Italian Reformation', in Petrarch in Britain, ed. Martin McLaughlin, Letizia Panizza, and Peter Hainsworth (Oxford, 2007), pp. 131-48.

${ }^{26}$ William J. Kennedy, Authorizing Petrarch (Ithaca NY, 1994).

${ }^{27}$ Catharina Ypes, Petrarca in de Nederlandse Letterkunde (Amsterdam, 1934); Jean Balsamo, 'Poetical and Political Readings of Petrarch's Rime in XVIth-Century France: A Critical Revaluation', in Karl A. E. Enenkel and Jan Papy (eds), Petrarch and bis Readers in the Renaissance, (Leiden, 2006), $261-85$.

${ }^{28}$ Andrew W. Taylor, 'Glass Houses: Surrey, Petrarch, and the Religious Poetics of the 'London' Invective', RES, 57 (2006), 433-55; David Norbrook, Poetry and Politics in the English Renaissance (London, 1984), 45-47.

${ }^{29}$ Nardo, Milton's Sonnets and the Ideal Community, 201.

30 ‘Hilario’ [Pier Paulo Vergerio] (ed), Stanze del Berna con tre sonetti del Petrarca dove si parla dell'euangelio, \& della corte Romana (n.p., 1554).

${ }^{31}$ For a typical example, see John Marbeck, The Holie Historie of King David (London, 1579), sig. $\mathrm{A} 2^{\mathrm{v}}$.

32 [Perrot, Nicholas], Aviso piacevole dato alla bella Italia... ([London], 1586). There is an excellent account of this work, which focuses on the Dantean, rather than Petrarchan, poems, in Jean Balsamo, 'Dante, L’aviso piacevole et Henri de Navarre', Italique, 1 (1998), 79-94.

${ }^{33}$ See Lambert Daneau, A Treatise Touching Antichrist, trans. J. Swan (London, 1589) sigs. Bb3 ${ }^{\mathrm{r}}-$ $\mathrm{Cc} 1^{\mathrm{r}}$.

${ }^{34}$ Ibid. sig. Bb3r.

35 W.I., Two Discourses of Master Frances Guicciardin, (London, 1595).

${ }^{36}$ For an account of the publication of Perna's volume and its subsequent English edition, see Eiléan Ní Chuilleanáin and Deirdre Serjeantson, 'The Petrarch They Tried to Ban: Francesco Guicciardini and the Canzoniere's Babylon Sonnets', in Cormac Ó Cuilleanáin and David Parris (eds), Literary Translation and Censorship (Dublin, 2009), 93-105. 
${ }^{37}$ See Robert Dallington, Aphorismes Civill and Militarie (London, 1613), sigs. Yy $2^{\mathrm{v}}$ and Xx4 ${ }^{\mathrm{r}}$ for 'Fiamma dal ciel' and 'Fontana di dolore', respectively.

${ }^{38}$ Bibl. Reg. 17.C.ix, reprinted in 'Defence of the true and old authority of Christ's Church by Coelius Secundus Curio' in Robert Eden (ed), The Examinations and Writings of John Philpot, B.C.L., Arcbdeacon of Winchester: Martyr 1555, (Cambridge, 1842).

${ }^{39}$ Ibid., 322.

40 Oxford, Bodleian Library, MS Fairfax 40, 604.

${ }^{41}$ The forthcoming Jackson Campbell Boswell and Gordon Braden (eds), Petrarch's English Laurels, 1475-1700: A Compendium of Printed References and Allusions, (Ashgate) will undoubtedly bring many more references to light.

${ }^{42}$ J.W. Lever, The Elizabethan Love Sonnet (London, 1956).

${ }^{43}$ Bernard Garter, A Nenyeares Gifte Dedicated to the Popes Holinesse (London, 1579), sigs. D1 ${ }^{\mathrm{r}}-\mathrm{D} 2 \mathrm{r}$.

${ }^{44}$ Mark Eccles, 'Barnabe Barnes', in Charles Sissons (ed.) Thomas Lodge and Other Elizabethans, (Cambridge MA, 1933), 165-242.

45 Alexander Garden, A Garden of Grave and Godlie Flowres: Sonets, Elegies, and Epitaphs (Edinburgh, 1609), sig. G4r.

${ }^{46}$ Consider, for instance, the description of the False Florimell (3.8.7) whose hair like golden wires and lamps for eyes conjure up the excesses of petrarchan imitation.

${ }^{47}$ See Barbara Lewalski, Protestant Poetics and the Seventeenth Century Religious Lyric (Princeton, 1979), 4.

${ }^{48}$ R. F Hall, 'Milton's Sonnets and his Contemporaries', in Dennis Danielson (ed.), The Cambridge Companion to Milton (Cambridge, 1999), 98-112 (98).

${ }^{49}$ Janel Mueller, ‘The Mastery of Decorum as Poetry in Milton's Sonnets’, Critical Inquiry, 13 (1987), 475-508, (477).

${ }^{50}$ Milton's appropriation of Petrarch's rhyme scheme has been noted by several critics, including F.T. Prince, The Italian Element in Milton's Verse, p. 63. Although Prince does not discuss the religious significance of Milton's substition of an incident from the life of Christ for a hymn of praise to the Virgin, he is appropriating a distinctively Catholic text for Protestantism. 
51 Aspettando ragion mi struggo et fiacco; ma put novo soldan veggio per lei ... Gl'idoli suoi sarranno in terra sparsi / et le torre superbe al ciel nemiche, / e i suoi torrer di for come dentro arsi. // Anime belle et di virtute amiche / terranno il mondo, et poi vedrem lui farsi / aureo tutto et pien de l'opre antiche. Canzoniere 137:5-6, 9-14.

52 Although see Elizabeth Sauer, 'Tolerationism, the Irish Crisis, and Milton's Late Massacre in Piemont', Milton Studies, 44 (2005), 40-61, at p. 44, for an interesting alternative reading of 'triple Tyrant' as a reference to the combined forces of the Duke of Savoy, the French army, and several Irish regiments.

${ }^{53}$ For an example from Milton's later years, see Edward Stillingfleet, $A$ Discourse Concerning the Idolatry Practised in the Church of Rome (London, 1671).

${ }^{54}$ There is a thorough account of Milton's references to the sect in William B. Hunter, 'Milton and the Waldensians', Studies in English Literature, 1500-1900, 11 (1971), 153-64.

55 Morland, Samuel. The History of the Evangelical Churches of the V alleys of Piemont (London, 1658), $\mathrm{a} 4 \mathrm{r}$.

${ }^{56}$ Ibid. a3 ${ }^{\mathrm{r}}$; $2^{\mathrm{v}}-\mathrm{c} 3^{\mathrm{r}}$.

${ }^{57}$ Ibid. $\mathrm{c}^{\mathrm{r}-\mathrm{v}}$.

58 'Milton's Commonplace Book', ed. Ruth Mohl, in Complete Prose Works I:344-513.

${ }^{59}$ Bodl. MS. Rawl. D. 929, 'Juvenile Collecting of the Famous Joseph Mead'. The Petrarch translation appears on $27 \mathrm{r}$, entitled 'The discriptione of hell.' The title of 'juvenile collecting' appears to be a later addition: on $21^{\mathrm{r}}$ there is a 'dolefull epigrame on the death of Queene an [sic] who dyed at Hampton Court the 2 day of March anno Domini 1618', which would have made Mede about 32 when he composed the poem.

${ }^{60}$ Jackson Campbell Boswell, Milton's Library: A Catalogue of the Remains of John Milton's Library (New York, 1975), 189.

${ }^{61}$ Simon Birckbek, The Protestants Evidence (London,1634), sig. Dd7r.

${ }^{62}$ William Guild, Anti-Christ Pointed and Painted out in His True Colours (Aberdeen, 1655), sig. $\mathrm{c1}^{\mathrm{r}}$.

${ }^{63}$ Petrarch, Opera Quae Extant Omnia (Basle, 1581) sig. +2v. 
${ }^{64}$ See the book list provided in John Craig, Reformation, Politics and Polemics: The Growth of Protestantism in East Anglian Market Towns, 1500-1610 (Aldershot, 2001), Appendix 6.

${ }^{65}$ E.S. Leedham-Green (ed.), Books in Cambridge Inventories: Book-Lists from the Vice-Chancellor's Court Probate Inventories in the Tudor and Stuart Periods, 2 vols (Cambridge, 1986). 